\title{
Prevelance, risk factors and adverse perinatal outcomes of bacterial vaginosis in pregnancy
}

\author{
Prasanna Kumar Shetty ${ }^{1 *}$, Akhila G. Menon ${ }^{1}$, Rekha Rai ${ }^{2}$
}

\begin{abstract}
${ }^{1}$ Department of Obstetrics and Gynaecology, ${ }^{2}$ Department of Microbiology, KS Hegde Medical Academy, Nitte (deemed to be) University, Deralakatte, Mangaluru, Karnataka, India
\end{abstract}

Received: 13 July 2021

Revised: 10 August 2021

Accepted: 11 August 2021

\section{*Correspondence:}

Dr. Prasanna Kumar Shetty,

E-mail: prasannashetty@ nitte.edu.in

Copyright: (C) the author(s), publisher and licensee Medip Academy. This is an open-access article distributed under the terms of the Creative Commons Attribution Non-Commercial License, which permits unrestricted non-commercial use, distribution, and reproduction in any medium, provided the original work is properly cited.

\section{ABSTRACT}

Background: Bacterial Vaginosis (BV) is the most common lower genital tract syndrome in women of age group 16 to 25 years.BV is a disorder of the vaginal microbial ecosystem characterized by a shift in the vaginal flora, from the normally predominant Lactobacillus species to one dominated by a mixed flora. The prevalence of BV can be around $15-30 \%$ and upto $50 \%$ in pregnancy. This study aims to study the prevalence of BV and their adverse outcomes on pregnancy.

Methods: It is a Cross Sectional Study at Department of Obstetrics and Gynecology, at a tertiary care hospital, for a period of one and half year from November 2016-April 2018.Pregnant women attending antenatal clinic were enrolled after obtaining an informed consent and vaginal swab examination done. The sample size was 200.

Results: The prevalence of BV in pregnant females was $18 \%$. The major risk factors for BV in pregnancy were young age, low socioeconomic status and recent sexual activity. All patients who took treatment for BV had good outcome. Amsel criteria had low sensitivity but very high specificity(95\%).Individually vaginal PH had a very high sensitivity $(91.6 \%)$ when compared to the gold standard Gram stain.

Conclusions: Routine screening is recommended for all pregnant women with risk factors and with symptoms. Early diagnosis and treatment in pregnant women who are asymptomatic and with no risk factors can prevent adverse outcome.

Keywords: Bacterial vaginosis, Amsel's criteria, Preterm labour, Chorioamnionitis

\section{INTRODUCTION}

Bacterial vaginosis (BV) is a disorder of the vaginal microbial ecosystem characterized by a shift in the vaginal flora, from the normally predominant Lactobacillus species (spp) to one dominated by a mixed flora including Gardnerella vaginalis, Prevotella spp, porphyromonas spp, Bacteroides spp, Mobiluncus spp and genital Mycoplasma spp..$^{1} \mathrm{BV}$ is associated with many obstetrical and gynaecological complications and is a strong independent risk factor for adverse pregnancy outcomes. ${ }^{2,3}$ The prevalence of BV can be around $15-30 \%$ and upto $50 \%$ in pregnancy. ${ }^{4}$ Women who have high concentration of $\mathrm{H}_{2} \mathrm{O}_{2}$ producing lactobacilli are less likely to have $\mathrm{BV}$ and remain persistently concentrated with lactobacilli. ${ }^{4,5}$

Obstetric and gynaecological complications mentioned are preterm labour and delivery, PPROM, spontaneous abortion, chorioamnionitis, post-partum endometritis, post-caesarean delivery wound infections, post-surgical infections, and subclinical pelvic inflammatory disease; low birth weight infants. ${ }^{2,6,7}$ Symptoms of BV includes homogenous white/grey discharge per vagina, pruritus, or malodour, but $50 \%$ of women with $\mathrm{BV}$ are asymptomatic. Early screening, with diagnosis and treatment of BV in pregnant women is helpful in preventing adverse outcome. 
Presently the predictors of BV have been confined to race, history of recent sexual activity, socioeconomic class and vaginal douching. ${ }^{8}$ There is major confusion regarding whether to test, screen or treat $\mathrm{BV}$ : also regarding the gestational age to start treatment. ${ }^{9}$

\section{METHODS}

The study design was cross Sectional. The study was conducted at an Antenatal clinic, Department of Obstetrics and Gynecology, KS Hegde Medical Academy under Nitte University. The study was carried out for a period of one and half years in the OBG Department from November 2016-April 2018.

\section{Study population}

Pregnant women attending antenatal clinic in the OBG Department of KSHEMA after obtaining an informed consent. The sample size was 200.The sociodemographic, medical/obstetric data of the subjects was collected by a structured questionnaire. Examination of the vaginal swab done.

\section{Sample size}

The Fischeres formula was used to calculate the valid sample size,

$$
n=\operatorname{DeffX} z^{2}(p X q) \div d^{2}
$$

Where, $\mathrm{n}$ - Required Sample size, Deff=design effect (set at 2), z - Standard normal deviate at the $95 \%$ confidence level (1.96), p - Estimated proportion proportion of patients with BV in ANC, KSHEMA (44\%,=0.44), dEstimated margin of error/level of significance (1\%.0.1), $\mathrm{q}=(1-\mathrm{p})$

Substituting the values in the above equation, we have, $\mathrm{n}=189.33=190$ study participants.

\section{Inclusion criteria}

Antenatal women 14-37 weeks of gestation, older than 18 years, planning to deliver at the study site, those with PROM and PPROM were included in the study.

\section{Exclusion criteria}

Antenatal women who used Antibiotics in the Past two weeks, who had antepartum Haemorrhage, who had advanced pre-term labour ( $>4 \mathrm{~cm}$ dilation) and those who had cervical Encerclage were excluded from the study.

\section{Method of sample collection}

In the OPD, following speculum examination of the subject, vaginal swab was taken and immediately transported to the laboratory for further examination. In case of delay of more than half an hour occurs, collected vaginal swab was smeared on a clean glass slide, a drop of normal saline applied, covered with a cover slip and kept inside a petri dish with wet cotton.

\section{Wet Mount examination}

The secretions from the swab were smeared on a clean glass slide and covered with a cover slip. The slide was first examined under low power followed by high power, to look for 'clue cells'. ${ }^{10}$

\section{Gram's staining}

The swab was smeared on another clean glass slide, air dried and fixed with gentle heat. Smear stained by Gram's staining method by adding crystal violet for one minute, wash with water, Gram's Iodine for one minute, wash with water, Acetone for 2-3 seconds, wash with water and dilute carbol fuchsin for one minute, wash with water. After air drying, the smear was examined under oil immersion objective for short Gram negative or Gram variable bacilli (Gardnerella vaginalis), curved Gram negative bacilli (Mobiluncus),epithelial cells with heavy coating of Gram negative bacilli on the periphery(clue cells) and thick Gram positive bacilli (Lactobacilli). ${ }^{11}$ The smear was graded and interpreted based on Nugent's score.

\section{Detection of $\mathrm{pH}$}

The vaginal swab was rubbed against a commercial $\mathrm{pH}$ paper and $\mathrm{pH}$ interpreted based on the colour scale provided by the manufacturer.

\section{Whiff's test}

Two drops of $10 \%$ potassium hydroxide was added on the swab and development of an amine fishy odour considered as a positive test, other than fishy odour as negative.

The diagnosis of bacterial vaginosis was made when three of the four following signs were present-Amsel's criteria. $^{12,13}$

An adherent and homogenous vaginal discharge. Vaginal $\mathrm{pH}$ greater than 4.5. Detection of clue cells. A positive Whiff's test. All the females included in the study were then followed up till delivery or post delivery till discharge.

Outcome was evaluated on basis of following: mode of delivery-lower segment caesarean section (LSCS) or normal vaginal delivery (NVD), term preterm or abortion, bacterial vaginosis present or absent, BV if present whether treatment was taken and relation of $\mathrm{BV}$ positive cases with PROM, neonatal sepsis and perinatal outcome.

\section{Statistical analysis}

Statistical analysis performed using software packages Statistical package for social sciences (SPSS) 15.0 and 
Epi-info 6. $\mathrm{P}$ value of 0.05 or less was considered significant.

\section{RESULTS}

Of the total 200 antenatal women included in the study, 36 (18\%) had BV including intermediate Bacterial vaginosis and $82 \%$ had normal vaginal flora. Intermediate BV constituted $5.5 \%(11 / 200)$ and BV alone constituted $12.5 \%$ $(25 / 200)$.

Table 1: Prevalence of Bacterial vaginosis.

\begin{tabular}{|lll|}
\hline Groups & $\mathbf{N}$ & $\%$ \\
\hline Normal vaginal flora & 164 & 82.0 \\
\hline Intermediate BV & 11 & 5.5 \\
\hline Bacterial Vaginosis & 25 & 12.5 \\
\hline Total & 200 & 100.0 \\
\hline
\end{tabular}

According to this study majority of patients were in the age group of 26-30 years, $(n=89,44.5 \%)$. All participants were married. $51.5 \%$ of the study population had primary education and $61.5 \%$ were employed.55\% of the study population was from upper lower (Class 4) of
Kuppuswamy classification of socioeconomic status.BV according to this study was prevalent in Class 4 socioeconomic class, that is 25 out of 36 cases $(69.4 \%)$ of the BV positive cases. This may attribute to poor hygiene being a risk factor for $\mathrm{BV}$.

It was found that vaginal discharge was absent in majority of the patients with BV $(86.1 \%)$. However, vaginal discharge was present in the majority of the participants with normal vaginal flora $(64.6 \%)$. $(\mathrm{p}=0.39)$.

It was also found that $\mathrm{pH}$ was higher in the majority of the participants with BV (91.6\%) and lower in majority of the participants with normal vaginal flora $(92.7 \%)$.

The sensitivity of $\mathrm{pH}$ was $91.6 \%$ and specificity was 92.6\%. The positive predictive value (PPV) was $73.3 \%$ and negative predictive value (NPV) $98.06 \%(\mathrm{p}=0.43)$. Majority of the participants with BV (84\%) and $91.4 \%$ of the participants with normal vaginal flora had recent sexual activity $(\mathrm{p}=0.91)$. Also clue cells were absent in the majority of the patients with Bacterial Vaginosis $(76 \%)$ and in all the patients with Intermediate Bacterial Vaginosis $(100 \%)(\mathrm{p}=0.07)$.

Table 2: Demographic details.

\begin{tabular}{|c|c|c|c|}
\hline \multicolumn{2}{|c|}{ Demographic factors } & $\mathbf{N}$ & $\%$ \\
\hline \multirow{4}{*}{$\begin{array}{l}\text { Age groups } \\
\text { (years) }\end{array}$} & $18-25$ & 67 & 33.5 \\
\hline & $26-30$ & 89 & 44.5 \\
\hline & $30-35$ & 36 & 18.0 \\
\hline & $>36$ & 8 & 4.0 \\
\hline \multirow{5}{*}{ Marital status } & Single & 0 & 0 \\
\hline & Married & 200 & 100 \\
\hline & Separated/Divorced & 0 & 0 \\
\hline & Widowed & 0 & 0 \\
\hline & Others & 0 & 0 \\
\hline \multirow{5}{*}{$\begin{array}{l}\text { Highest level of } \\
\text { Education }\end{array}$} & Informal & 29 & 14.5 \\
\hline & Primary & 103 & 51.5 \\
\hline & Secondary & 67 & 33.5 \\
\hline & College & 1 & 0.5 \\
\hline & University & 0 & 0 \\
\hline \multirow{2}{*}{ Occupation } & Employed & 123 & 61.5 \\
\hline & Unemployed & 77 & 38.5 \\
\hline \multirow{2}{*}{ Residence } & Rental & 187 & 93.5 \\
\hline & Owned & 13 & 6.5 \\
\hline \multirow{5}{*}{$\begin{array}{l}\text { Socio economic } \\
\text { status }\end{array}$} & Upper & 4 & 2 \\
\hline & Upper middle & 11 & 6 \\
\hline & Lower middle & 72 & 36 \\
\hline & Upper lower & 109 & 55 \\
\hline & Lower & 4 & 2 \\
\hline
\end{tabular}

According to this study, out of 200 participants, Nugent's scoring for BV was positive for a total of 36 patients, including 11 intermediate BV. The prevalence of BV was found to be $18 \%$ according to the gold standard Gram staining scored using Nugent's criteria. 
Table 2: Distribution of participants according to the Nugent's score.

\begin{tabular}{|c|c|c|c|c|c|c|}
\hline \multirow{2}{*}{ Nugent's score } & \multicolumn{2}{|c|}{ Normal vaginal flora } & \multicolumn{2}{|c|}{ Bacterial vaginosis } & \multirow{2}{*}{ Chi square } & \multirow{2}{*}{$P$ value } \\
\hline & $\mathbf{N}$ & $\%$ & $\mathbf{N}$ & $\%$ & & \\
\hline $0-3$ & 164 & 100.0 & 0 & 0 & \multirow{4}{*}{17.704} & \multirow{4}{*}{0.07} \\
\hline 4-6 & 0 & 0 & 17 & 47.2 & & \\
\hline$\geq 7$ & 0 & 0 & 19 & 52.7 & & \\
\hline Total & 164 & 100.0 & 36 & 100.0 & & \\
\hline
\end{tabular}

According to Amsels's criteria prevalence was found to be $14.5 \%$ comparable to the Nugent's scoring which was $18 \%$. The results from clinical diagnosis were validated against Gram's stain-the gold standard of diagnosis of BV. The sensitivity was low (9.2\%) but specificity was high (95\%) for the clinical criteria. ${ }^{14}$

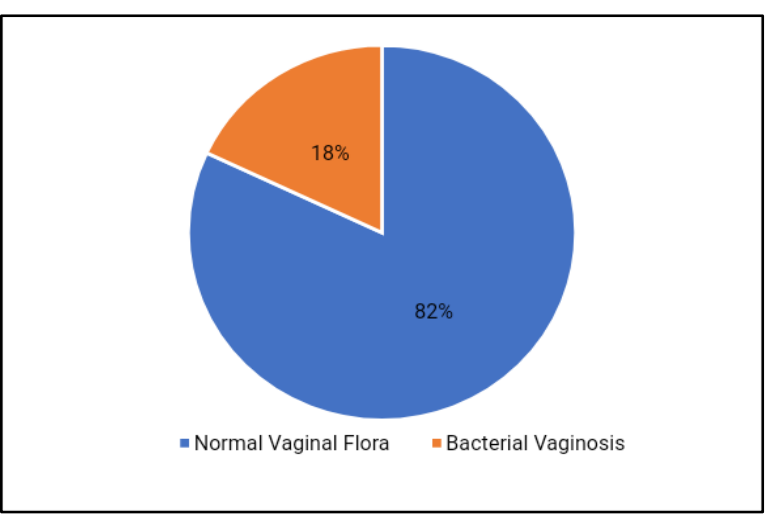

Figure 1: Prevalence of bacterial vaginosis.

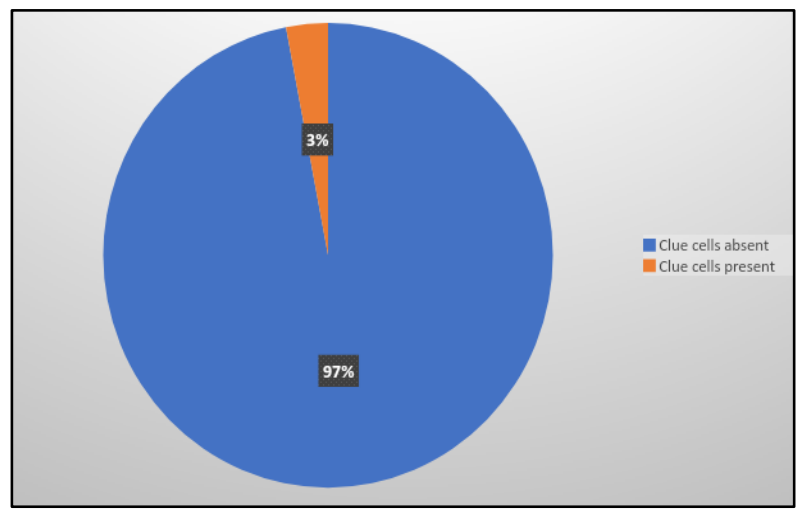

Figure 2: Presence of clue cells.

When all components of Amsel's criteria was evaluated against Gram staining it was found vaginal $\mathrm{pH}$ had highest sensitivity of $95 \%$ and PPV of $20.2 \%$. All other variables had high specificity of more than $95 \%$ except for clue cells which had a specificity of $84 \%$.

It was found all the participants with BV (100\%) had term delivery and majority of the participants with normal vaginal flora had term delivery $(94.5 \%)$. There was no preterm deliveries in $\mathrm{BV}$ positive cases according to this study.

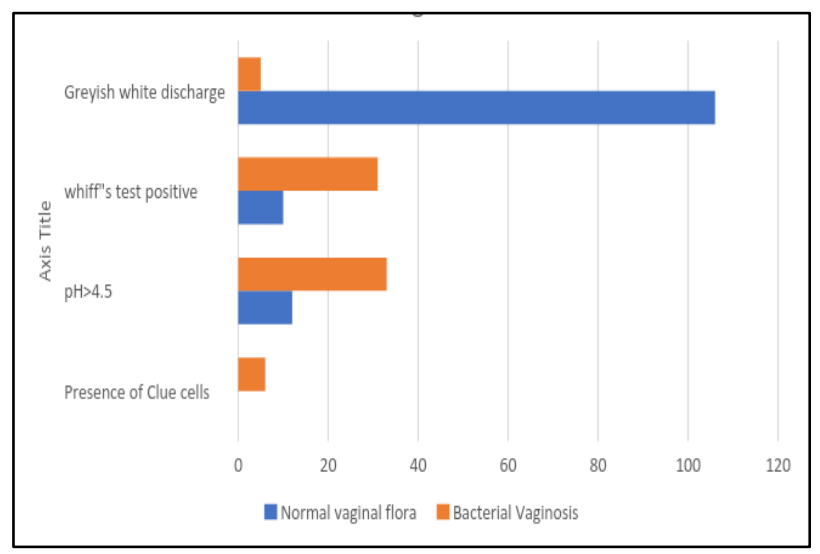

Figure 3: Distribution according to Amsel's criteria.

In this study only 5 of $25 \mathrm{BV}$ positive (13.8\%) had history of PROM which was statistically insignificant, 9 of 164 patients $(5.5 \%)$ in normal study group had PROM $(\mathrm{p}=0.58) .15$ We had only $1(0.5 \%)$ patient with $\mathrm{BV}$ had neonatal sepsis.16 Baby had meconium aspiration syndrome and following which developed sepsis but not related to $\mathrm{BV}(\mathrm{p}=0.06)$. It was found that the mean birth weight was higher in participants with Intermediate Bacterial Vaginosis (3.12 \pm 0.11$)$. The mean gestational age at the time of delivery being $36 \pm 3.1$ years in Intermediate Bacterial Vaginosis patients and $37 \pm 3.5$ years in participants with Bacterial Vaginosis.

\section{DISCUSSION}

Bacterial vaginosis is the commonest LGT disorder among women of reproductive age (pregnant and non pregnant) and the most prevalent cause of vaginal discharge, itching and malodour. ${ }^{6}$ The diagnosis of BV is based on clinical findings and laboratory testing. BV can be diagnosed by Gram's staining-the gold standard method and clinically by Amsel's criteria. In our study we diagnosed by Nugent's scoring as per inclusion criteria and compared with Amsel's criteria. Bacterial vaginosis can also be diagnosed by Spiegel's and Nugent's criteria. Schwebke et al showed that Nugent's score was more sensitive than Amsel's criteria for diagnosis of $\mathrm{BV}$ as it is simple, easy, cost effective, fast and reliable. ${ }^{17} \mathrm{We}$ found out $18 \%$ prevalence according to Nugent's scoring and $14.5 \%$ according to 
Amsel's criteria. Studies have documented similar prevalence rates in pregnant and non-pregnant populations.

In a study by Yudin et al in 2008, a prevalence rate of 6$32 \%$ was found; another Canadian study in 2002 on maternity patients reported an overall prevalence of $\mathrm{BV}$ of $14 \%{ }^{6,18}$ Purwar et al in 2001with a sample of 1,006 pregnant women from Nagpur found a prevalence of BV $11.53 \%$. According to the present study BV was found to be more prevalent in young age group of 26-30 years $(47.2 \%)$, followed by $18-25$ years $(30.5 \%)$. The finding of $\mathrm{BV}$ being more in younger age is similar to that Of Larsson et al 2007 who found BV is more common among smokers and higher prevalence in the younger age group but dissimilar to study by Purwar et al 2001 and Jones et al 2007 who found increase prevalence with increasing age. $^{19-21}$

The risk factors mentioned by Yudin et al being black women, smoking, women who are sexually active compared with virginal women and those who use vaginal douches. Deborah et al mentioned the risk as race-African Americans, sexual activity, socioeconomic status lower having higher risk than higher economic status which they assumed to be due to stress and vaginal douching. ${ }^{4,6}$ In our study $86.4 \%$ of BV positive patient had recent sexual activity suggesting it as a risk factor. UTI is also a known risk factor of $\mathrm{BV}$ in pregnant women. ${ }^{22}$ In this study among 200 antenatal participants, during the study period 111 (55\%) women had white discharge PV, among which only 5 were BV positive, accounting to $2.5 \%$ of the study population and $13.8 \%$ of total BV positive cases. A study by Mengistie et al gives a similar result saying majority are asymptomatic with prevalence of BV $19.4 \%$ using Nugent scoring. Our study showed a sensitivity of $95.1 \%$ and specificity of $3.1 \%$ in diagnosing $\mathrm{BV}$ if $\mathrm{pH}$ is used as an individual diagnostic tool. Vaginal $\mathrm{pH}$ of $>4.5$ had the highest sensitivity $(95.1 \%)$ individually for diagnosing BV compared to the other three components of the Amsel criteria with PPV of $73.3 \%$ and NPV of $98.06 \%$.

In this study BV was found to be more prevalent in primi gravidas 21 of 36 cases. All BV positive had term deliveries. A study by Cheryl et al included case control and cohort studies and evaluated the risk of preterm delivery, low birth weight, PPROM, or preterm labor for pregnant women who had BV and summarized BV a significant risk factor. ${ }^{23}$

Jane et al University of Alabama at Birmingham 2009 who found women with intermediate flora may also be at risk for complications, especially if associated with absence of lactobacilli. ${ }^{24}$ Some study found that $6 \%$ of Intermediate convert to $\mathrm{BV}, 37 \%$ still continue to have intermediate flora and $59 \%$ revert to normal flora, but in this study repeat sample was not taken. ${ }^{25}$ The current opinion on BV with pregnancy is all women with symptomatic BV should be treated to relieve bothersome symptoms. ${ }^{26}$
Yudin et al gave few recommendations on screening viz: ${ }^{6}$

In symptomatic pregnant women,testing and treatment of $\mathrm{BV}$ is recommended for symptom resolution. Pregnant women with asymptomatic BV can be treated with oral or vaginal medications for curing women at low risk of bad obstetric outcomes. Women at high risk for preterm birth may benefit from routine screening for and treatment of BV. Treatment for prevention is metronidazole $500 \mathrm{mg}$ orally twice daily or clindamycin $300 \mathrm{mg}$ orally twice daily for seven days. Topical (vaginal) therapy is not recommended. Testing should be repeated one month after treatment to ensure complete cure.

\section{CONCLUSION}

The prevalence of BV in pregnant females was $18 \%$ which lies within the reported range for this region. The major risk factors for $\mathrm{BV}$ in pregnancy were young age, low socioeconomic status and recent sexual activity. Majority of the patients were asymptomatic. All patients who took treatment for BV had good outcome. No adverse outcome was noted related to BV according to present study. Routine screening is recommended for all pregnant women with risk factors and with symptoms as early diagnosis and treatment in pregnant women can prevent adverse outcome. The same is attributed to asymptomatic women as routine screening helps to detect $\mathrm{BV}$ at the earliest. Individually vaginal $\mathrm{PH}$ had a very high sensitivity $(91.6 \%)$ when compared to the gold standard Gram stain. We demonstrated that detection of BV is accurate but has low sensitivity but very high specificity (95\%) by Amsel's criteria. Our results supports the same as an easy to use screening tool for BV during antenatal care. Also this enables early screening, detection and treatment of $\mathrm{BV}$ during pregnancy and might therefore contribute a future reduction in the rate of preterm birth. Bacterial vaginosis prevalence was affected by some hygiene behaviours, socio-demographic and clinical characteristics. We therefore recommend that pregnant women seeking antenatal care in study area should be routinely screened for BV and other genital tract infections apart from those under routine investigation, and positive cases treated to avoid negative outcomes. There is need for comprehensive, educational health programs, aimed at reducing $\mathrm{BV}$ prevalence and guide the planning and resource allocation of decision makers for future interventions and research.

Funding: No funding sources

Conflict of interest: None declared

Ethical approval: The study was approved by the Institutional Ethics Committee

\section{REFERENCES}

1. Hill GB. The microbiology of bacterial vaginosis. Am J Obstet Gynecol. 1993;169:450-4.

2. Shetty AK, DaviSB. Screening of bacterial vaginosis in pregnancy and its outcome on pregnancy. 
Intemational journal of A J Institute Of medical science. 2012;1:20-5.

3. Guise JM, Mahon SM, Aickin M, Helfand M, Peipert JF, Westhoffc. Screening for bacterial vaginosis in pregnancy. Am J Prev Med. 2001;20:62-72.

4. Deborah B, Nelson, Macones G. Bacterial Vaginosis in Pregnancy: Current Findings and Future Directions Epidemiol Rev. 2002;24:102-8.

5. Mittal V, Jain A, Pradeep Y. Development of modified diagnostic criteria for $\mathrm{g}$ countries. J Infect Dev ctries. 2012.

6. Yudin MH, Money DM, Boucher M, Cormier B, Gruslin A, Ogilvia G. Bacterial vaginosis Pregnancy. Soge clinical practice guideline. 2008;211:702-8.

7. Romero R, Espinoza J, Gotsch F, Kusanovic JP, Friel LA, Erez $\mathrm{O}$ et al. The use of high dimensional biology (genomics, transcriptomics, proteomics and metabolomics) to understand the preterm parturition syndrome. Br J Obstet Gynaecol. 2006;113(S3):118.

8. De Seta A, Sartore M, Piccoli. Bacterial vaginosis and preterm delivery: an open question. J Reprod Med. 2005;50:313-8.

9. US Preventive Services Task Force. Screening for bacterial Vaginosis in pregnancy to prevent preterm delivery.US Preventive Services Task Force recommendation Statement. Ann Intern Med. 2008;148:214-9.

10. Gardner H, Dukes C D. Haemophilus vaginalis vaginitis. A newly defined specific infection previously classified "nonspecific" vaginitis. Am J Obstet Gynecol. 1955;69:962-76.

11. Gram' staining. www.microrao.coWmicronotes /pg/Gram\%20stain.pdf. Accessed on 10 ${ }^{\text {th }}$ May, 2021.

12. Sobel JD. UpTODate. http://www.uptodate.com /contents/approach-to-women-with-smptoms-ofvaginitis. Accessed on 10 $0^{\text {th }}$ May, 2021.

13. Amsel R, Totten PA, Spiegel CA, Chen KCS, Eschenbach DA, Holmes KK. Nonspecific vaginitis. Am J Med.1983;74:14-22.

14. Rajeshwar SR, Pindi G, Rani U, Sasikala G, Kawle V. Diagnosis of Bacterial Vaginosis:Amsel's Criteria vs Nugent's scoring. Journal of Applied Medical Sciences. 2016;4(6C):2027-31.

15. Flynn CA. Bacterial Vaginosis in Pregnancy and the Risk of Prematurity A Meta-Analysis. J Fam Pract. 1999;48(11):885-92.

16. Svare JA, Ringvej DK. 2600. Glostrup, Denmark.
17. Schwebke JR. Vaginal infections. In: Goldman MB, Hatch MC, eds. Women and health. San Diego, CA: Academic. 2000

18. Wenman WM, Tataryn IV, Joffres MR, Pearson R, Grace MOA, Albritton et al. Demographic, clinical and microbiological characteristics of matemity patients: a Canadian clinical cohort study. Can J Infect Dis. 2002;13(5):311-8.

19. Larsson PG, Fåhraeu L, Carlsson B, Jakobsson T, Forsum U. Predisposing factors for bacterial vaginosis, treatment efficacy and pregnancy outcome among term deliveries; results from a preterm delivery study. BMC Womens Health. 2007;7:20.

20. Purwar M, Ughade S, Bhagat B, Aganval V, Kulkarni $\mathrm{H}$. Bacterial vaginosis in early pregnancy and adverse pregnancy Outcome. J Obstet Gynaecol Res. 2001;27(4):175-81.

21. Jones FR, Miller G, Gadea N, Meza R, Leon S, Perez $\mathrm{J}$ et al. Prevalence of bacterial vaginosis among young women in low-income populations of coastal Peru. Int J STD AIDS. 2007;18:188-92.

22. Lata I, Pradeep Y, Sujata, Jain. Estimation of the Incidence of Bacterial Vaginosis and other Vaginal Infections and its Consequences on Maternal/Fetal Outcome in Preplant Women Attending an Antenatal Clinic in a Tertiary Care Hospital in North India. Indian J Community Med. 2010;35(2):285-9

23. Flynn CA. Bacterial Vaginosis in Pregnancy and the Risk of Prematurity A Meta-Analysis. J Fam Pract. 1999;48(11):885-92.

24. Schwebke JR. Bacterial Vaginosis: Are We Coming Full Circle? JID. 2009;200:1662-70.

25. Morris M, Nicoll A, Simms I, Wilson J, Catchpole M. Bacterial vagnosis: A public health review. BJOG. 2001;108:439-50.

26. Hay PEI, Morgan DJ, IsonBhide SA, Romney M, McKenzie P, Pearson J et al. A longitudinal study of bacterial vaginosis during pregnancy.Br $\mathrm{J}$ Obstet Gymaecol. 1994;1048-53.

27. Sobel JD. UpTODate. http://www.uptodate.com/ contents/approach-to-women-with-smptoms-ofvaginitis. Accessed on $10^{\text {th }}$ May, 2021.

Cite this article as: Shetty PK, Menon AG, Rai R. Prevelance, risk factors and adverse perinatal outcomes of bacterial vaginosis in pregnancy. Int $\mathbf{J}$ Reprod Contracept Obstet Gynecol 2021;10:3407-12. 